Turyzm 2020, 30/2

\author{
Sławoj Tanaś \\ https://orcid.org/0000-0003-3325-2645 \\ Uniwersytet Łódzki \\ Wydział Nauk Geograficznych \\ Instytut Geografii Miast, Turyzmu i Geoinformacji \\ slawoj.tanas@geo.uni.lodz.pl
}

\title{
SFERA PROFANUM DNIA WSZYSTKICH ŚWIĘTYCH WOBEC SPOŁECZNEGO ASPEKTU CMENTARZY
}

\begin{abstract}
Abstrakt: Współczesna „popkulturyzacja” uroczystości Wszystkich Świętych stała się powodem do dokonania przez autora analizy sfery profnum tego dnia na przykładzie wybranych łódzkich cmentarzy, wraz z krótkim opisem porównawczym latynoamerykańskich świąt ku czci zmarłych, które przypadają na pierwsze dni listopada. Odwiedzanie polskich cmentarzy 1 listopada nabrało w XX w. cech rekreacyjnych i krajoznawczych, co potwierdzają m.in. sposób zagospodarowania otoczenia cmentarzy, mający charakter jarmarczny i ludyczny, oraz kierujące odwiedzającymi motywy komemoracyjne, kontemplacyjne i poznawcze. Zmiany cywilizacyjne wpływają coraz częściej na postrzeganie dnia Wszystkich Świętych jako atrakcji turystycznej czy wręcz kulturowego produktu turystycznego. Artykuł obejmuje opis porównawczy uroczystości Wszystkich Świętych w Polsce i Dnia Zmarłych w Ameryce Łacińskiej, analizę pomiaru wielkości ruchu na wybranych łódzkich cmentarzach wraz ze sposobem zagospodarowania ich otoczenia w dniu 1 listopada 2019 r., z wykorzystaniem niepublikowanych wyników badań z 2004 r., oraz dyskusję nad świeckim i rekreacyjnym aspektem dnia Wszystkich Świętych.
\end{abstract}

Słowa kluczowe: dzień Wszystkich Świętych, Dzień Zmarłych, Łódź, Ameryka Łacińska, cmentarz, zagospodarowanie, wielkość ruchu.

\section{WSTĘP}

W kręgu kultury europejskiej, środkowo- i południowoamerykańskiej dni 1 i 2 listopada to czas odwiedzania grobów świętych, błogosławionych, przodków, zmarłych członków rodziny i bliskich osób. Odwiedziny cmentarzy na przełomie października i listopada służą zaspokojeniu potrzeb komemoracyjnych i religijnych. Źródłami świąt ku czci zmarłych były w szczególności: religia, obrzędowość, wiara w życie pozagrobowe oraz - co bardzo ważne z punktu widzenia geograficznego - synkretyzm kulturowy. Uroczystościom dnia Wszystkich Świętych i Dnia Zadusznego (Zaduszek) w Europie, obok sfery religijnej, towarzyszą od wieków ludowość i świeckość, obserwowane w wierzeniach, obrzędach i społecznych tradycjach (Ariés, 1989; Kolbuszewski, 1996).

Europejskie cmentarze, umiejscawiane w średniowieczu wokół świątyń, jednoczyły lokalną społeczność za sprawą grobów (wspominanie zmarłych, wiara w życie pozagrobowe), obrzędów (procesje, modlitwy, ceremoniał) i wydarzeń (handel, jarmarki, sądy, egzekucje). W wyniku rewolucji kulturowej z przełomu XVIII i XIX w. zmienił się sposób lokowania i organizacji cmentarzy, a zmarłym przywrócono miejsce w centrum życia społecznego. Zmarły miał być od tej chwili blisko żywych, już nie tylko poprzez modlitwę i wspomnienie, ale przede wszystkim przez grób, zlokalizowany na przyjaźnie zorganizowanym cmentarzu - w otoczeniu zieleni (cmentarz park) i sztuki (cmentarz galeria rzeźby sepulkralnej). Konsekwencją zaistniałych zmian było społeczne zredefiniowanie charakteru dnia Wszystkich Świętych i Zaduszek - do tej pory mniej znanych w mieście, a powszechnych na wsi, mających ściśle religijny i ludyczny charakter. Początek listopada stał się czasem odwiedzania indywidualnych grobów z ustanowionym ceremoniałem, mającym swój ustalony, ale geograficznie zróżnicowany kod kulturowy, poddawany cyklicznym modyfikacjom, wynikającym z postępujących przemian społeczno-gospodarczych. Tym samym zmieniający się sposób życia mieszkańców miast wpłynął bezpośrednio na społeczny wymiar dnia Wszystkich Świętych, a kulturowe i religijne źródła tradycji stały się powodem mającego świecki charakter zainteresowania cmentarzami. Sfera profanum postępu cywilizacyjnego zaczęła mieć wpływ na sferę sacrum 
tradycji i obrzędowości (zob. też: Eliade, 1996; Jackowski, 2003).

Święta ku czci zmarłych obchodzone na początku listopada w krajach Ameryki Łacińskiej charakteryzują się szczególnymi cechami. Na cmentarzach i wokół nich odbywają się pikniki. Powszechną praktyką jest dekorowanie grobów kwiatami i świeczkami. Ponadto organizowane są parady osób przebranych za Śmierć w stroju kolonialnym z charakterystycznym kapeluszem. Panuje również zwyczaj konstruowania i puszczania kolorowych latawców, będących łącznikiem między żywymi a duszą zmarłego, oraz organizowania zabaw tanecznych. W sferze kulinarnej powszechne są tradycyjne wypieki i słodycze, a wśród nich m.in. lukrowane, cukrowe trupie czaszki. Tak odmienne dla europejskiego kręgu kulturowego zwyczaje są ściśle powiązane z ceremoniałem kościelnym, mszą i modlitwą oraz wspomnieniem zmarłych. Odmienny charakter latynoamerykańskiego Święta Zmarłych stał się czynnikiem sprzyjającym podróżom poznawczym mieszkańców Stanów Zjednoczonych i Europy, w szczególności do Meksyku, gdzie uroczystości ku czci zmarłych, odbywające się na przełomie października i listopada, mają wręcz wydźwięk karnawałowy i stały się uznanym produktem turystycznym.

Wskazane powody leżą u podstaw wyboru przez autora obszaru geograficznego, z którym porównał Polskę pod kątem obchodzenia święta ku czci zmarłych, mającego nie tylko cechy religijnej uroczystości, ale nasyconego również ludycznymi elementami jarmarczności, wykorzystywanymi w aspekcie rekreacyjnym. Wymienione obrzędy i zwyczaje mają charakter synkretyczny. Łączą one bowiem tradycje chrześcijańskie z prekolumbijskimi wierzeniami, tak jak dzień Wszystkich Świętych i Zaduszki w Europie spajają tradycję chrześcijańską z pogańskimi obrzędami (Ariés, 1989; Brandes, 1998a).

Dzień Wszystkich Świętych i Zaduszki w Polsce mają nieco odmienny charakter. W tych dniach odwiedzający groby są pogrążeni w zadumie i modlitwie. Brak jest tak charakterystycznej dla Ameryki Łacińskiej karnawałowości i zabawy. Wspólne posiłki odbywają się podczas rodzinnych obiadów w domach, a nie na cmentarzach. W Polsce nie puszcza się latawców, nie organizuje się parad ulicznych, nie eksponuje się symboliki śmierci, nie ma również tradycji przygotowywania wypieków i posiłków dla zmarłych. W niektórych miastach zwyczajowo sprzedaje się jednak okolicznościowe słodycze: pańską skórkę w Warszawie, miodek turecki w Krakowie i szczypki na Lubelszczyźnie.

Z pewnością można jednak wskazać wspólne elementy analizowanych świąt ku czci zmarłych, takie jak: czyszczenie grobów i dekorowanie ich kwiatami, zapalanie zniczy, wspólne modlitwy za dusze zmarłych i liczne odwiedzanie mogił. To właśnie masowość wizyt na cmentarzach, ozdobność grobów i wieczorny klimat rozświetlonych zniczami cmentarzy spowodowały, że w Polsce dzień Wszystkich Świętych, podobnie jak np. w Meksyku Dzień Zmarłych, traktowany jest jako produkt turystyczny z grupy istotnych świąt narodowych i religijnych, promowanych przez Polską Organizację Turystyczną.

W dobie przemian społeczno-gospodarczych, zachodzących w Polsce po 1989 r., można zaobserwować próby powrotu do sposobu świętowania z przełomu XIX i XX w. Jarmarczny i ludyczny charakter straganów, zlokalizowanych w otoczeniu cmentarzy, mała gastronomia, handel balonami, lodami, watą cukrowa, preclami czy zabawkami wskazują na świecki sposób świętowania tego dnia w gronie rodziny i znajomych. Taka forma obchodzenia świąt ku czci zmarłych wzbudza oczywiście protesty Kościoła katolickiego i części konserwatywnego społeczeństwa, ale współczesne pokolenie Z inaczej, wręcz w sposób popkulturowy, traktuje dzień Wszystkich Świętych, coraz częściej łącząc go z wigilią 1 listopada i zapożyczonym, świeckim świętem Halloween, mającym raczej wymiar karnawałowy i komercyjny.

\section{CMENTARZ JAKO MIEJSCE WYDARZEŃ}

Człowiek i kształtowana przez niego kultura to ściśle powiązane ze sobą elementy, stanowiące o charakterze przestrzeni poznawczej i rekreacyjnej. Cechy tych przestrzeni mają np. cmentarze (Stasiak, Tanaś, 2005).

W XVIII i XIX w. projektanci cmentarzy miejskich, na kanwie rozwijającej się myśli oświeceniowej, a później pozytywistycznej, zapoczątkowali w Europie proces organizacji cmentarzy, uwzględniając nie tylko kwestie użytkowe (grzebanie zwłok) czy religijne (więź z sacrum), ale również zmieniające się potrzeby mieszkańców wielkich miast, wynikające m.in. ze wzrostu ilości czasu wolnego ${ }^{1}$. Cmentarze stały się miejscem romantycznej kontemplacji, regeneracji psychofizycznej oraz odpoczynku od zgiełku miasta. Ponadto dostarczały doznań estetycznych i emocjonalnych. Podobnie jak zakładane w tym czasie parki i ogrody, cmentarze stały się miejską enklawą zieleni, w której odbywano spacery i realizowano zupełnie inne cele niż do tej pory.

Cmentarz jest zbiorem grobów i wydaje się, że to właśnie one stanowią główny cel odwiedzin. Grób jest społeczną i emocjonalną przestrzenią stworzoną wokół zmarłego, symbolizującą umownie jego pośmiertny dom. Na ten symbol składa się wiele zewnętrznych znaków, m.in. forma grobu, rzeźba, epigrafika, oprawa roślinna, co sprawia, że cmentarz można uznawać za swoisty tekst kultury (Kolbuszewski, 1985). Charakter nekropolii i jego semantyczną ekspresję kształtują cechy kulturowo-emocjonalne, a interpretacja cmentarza, w zależności od zakorzenienia kulturowego, w jakimś 
stopniu pełni funkcję łącznika między współczesnością a przeszłościa, między żywymi a umarłymi.

W 2. połowie XIX w. pozytywiści wprowadzili modę na kult grobów, co w konsekwencji doprowadziło do zmiany w nastawieniu społeczeństwa do nagrobków, mianowicie przestały one być anonimowe, i do cmentarzy, które w następstwie stały się tekstami kultury artystycznej, obiektami godnymi poznania, literackiej deskrypcji, naukowego i podróżniczego opisu (Ariés, 1989). Tym samym pojawiła się idea organizowania przestrzeni cmentarnej, mająca ułatwić uprawianie kultu zmarłych, zdefiniowanego również jako jeden z podstawowych elementów poczucia obywatelskości. Idea ta była propagowana przez Kościół katolicki, który po wielowiekowej tradycji wspominania zmarłego jedynie przez modlitwę, szczególnie w świątyni, powrócił do indywidualnego kultu zmarłych oraz nawiedzania grobu. W XIX w. na cmentarzach odbywał się więc nowy rytuał, polegający na obowiązku cyklicznego odwiedzania mogit.

Nowo organizowana przestrzeń grzebalna stała się swego rodzaju parkiem pamięci, celem wizyt indywidualnych i rodzinnych, muzeum na otwartej przestrzeni oraz miejscem sprzyjającym zadumie i refleksji. W Anglii, Francji i Stanach Zjednoczonych idee cmentarzy ogrodów i cmentarzy parków, projektowanych z myślą o odwiedzających, miały łączyć w sobie walory krajobrazowe z wykorzystaniem zieleni i architektury oraz walory społeczne, takie jak: historia, tradycja, artyzm i religia. Parkowa lub ogrodowa forma cmentarza miała stanowić tło refleksji i wspomnień o zmarłych, grunt dla poradzenia sobie z traumą po utracie bliskiej osoby, sprzyjając poprawie stanu psychicznego i zachęcając do regeneracyjnych spacerów w przyjaznym otoczeniu. Wielkomiejskie nekropolie stały się alternatywą dla parków, terenem zieleni, szczególnie istotnym na obszarach rozrastających się gwałtownie w XIX w. miast, poddawanych niekontrolowanej industrializacji (Długozima, 2011; Tanaś, 2008). Cmentarz przestał być już tylko miejscem średniowiecznego, chaotycznego pochówku i stał się przestrzenią pamięci i wspomnień, sprzyjającą uspokojeniu myśli i emocji, a także regeneracji, będącej składową później zdefiniowanej rekreacji. Cmentarz, w wyniku upowszechnienia rzeźby sepulkralnej, zaczął pełnić również funkcję galerii sztuki, a więc miejsca doznań estetycznych i kształtowania artystycznej mody.

Cmentarz jest miejscem obrzędowości, której istotną składową stanowią uroczystości pogrzebowe i wspomnieniowe, zarówno o charakterze religijnym, jak i świeckim. W zależności od obowiązujących norm kulturowych na cmentarzach organizowane są wydarzenia i uroczystości. W określonych terminach w ciągu roku skupiają się tam lokalne społeczności lub coraz częściej turyści, chcący być świadkami niecodziennych spotkań. Do takich wydarzeń należy zaliczyć w szczególności uroczystości pogrzebowe, zróżnicowane geograficznie pod względem charakteru i rytuału, oraz wspomnieniowe, jak: europejski dzień Wszystkich Świętych i Dzień Zaduszny, meksykański Dzień Zmarłych czy japońskie święto Bon, ale także uroczystości wielkanocne z tradycją odwiedzania mogił najbliższych osób na wzór nawiedzenia grobu Chrystusa czy zwyczaj chodzenia na cmentarze w okresie Zielonych Świątek, szczególnie zachowany w Kościele prawosławnym.

Cmentarz, ze względu na swoją oprawę przyrodniczo-architektoniczna, jest miejscem organizowania wydarzeń artystycznych, np. koncertów muzyki poważnej, koncertów dla uczczenia pamięci zmarłych. Wydarzenia takie odbywają się np. na cmentarzu Centralnym w Szczecinie, cmentarzu Ohlsdorf w Hamburgu czy cmentarzu Skogskyrkogården w Sztokholmie.

Wydarzenia na cmentarzach, nie tylko te o charakterze religijnym, ale także świeckim, stały się współcześnie celem podróży poznawczych (turystycznych), są promowane wielokrotnie jako atrakcje turystyczne, a nawet produkt turystyczny. Nie jest to jednak domena współczesności. Zarówno w średniowieczu, jak i w kolejnych wiekach publiczność gromadziła się w obrębie cmentarzy przykościelnych, na których odbywały się nie tylko uroczystości religijne, ale również świeckie. Cmentarze stanowiły miejsce sądów, spotkań lokalnej wspólnoty, sejmików, postoju pielgrzymek, pochodów i procesji, a także przesłuchań, tortur i egzekucji. Nekropolie i ich otoczenie pełniły funkcję targowisk podczas świąt, w ich obrębie organizowano także jarmarki.

Cmentarz, podobnie jak kościół, był - i w pewnym sensie nadal jest - miejscem azylu, a co za tym idzie - z czasem przekształcił się w siedzibę żywych i w publiczne miejsce spotkań. Na cmentarzu chronili się zbiegowie i bezdomni, co skutkowało ich zamieszkiwaniem w kostnicach bądź w niewielkich, budowanych w pośpiechu domkach (Ariés, 1989). W Ameryce Łacińskiej nadal można zobaczyć zaadaptowane na potrzeby mieszkańców grobowce, szczególnie w wielkomiejskich dzielnicach biedy, np. cmentarz Północny w Manili (Filipiny). Cmentarz, ze względu na lokalizację $\mathrm{w}$ bezpośredniej bliskości kościoła, pełnił niejednokrotnie funkcję rynku, był ruchliwym i hałaśliwym miejscem w mieście i na wsi. Wynikało to z faktu, że w budynku kościoła, stanowiącego centrum życia miejskiego i wiejskiego, nie zawsze mogli się pomieścić wierni, stąd cmentarz przykościelny, jako dziedziniec kościoła, był wykorzystywany w najróżniejszy sposób - np. procesje w Niedzielę Palmową czy w święto Bożego Ciała odbywały się na terenie przyozdobionego wówczas cmentarza.

Opisane przykładowe praktyki były negowane przez Kościół, ale - podobnie jak w przypadku pochówku w świątyniach - społeczeństwo łamało ustanawiane zakazy dotyczące miejsc należących do wspólnoty. W średniowieczu tego typu zachowania nie były 
uznawane za naganne. Również na polskich cmentarzach, wbrew nakazom Kościoła, odbywały się jarmarki, zebrania, wiece, a nawet huczne imprezy (chociażby w dniu Wszystkich Świętych). Niemniej jednak zgodnie z decyzjami kolejnych synodów organizowanie świeckich wydarzeń w obrębie cmentarzy było zabronione.

Cmentarz był i nadal pozostaje aktywną i ważną przestrzenią publiczna, pomimo że od XVI w. funkcję miejsca publicznego zamiast cmentarzy coraz częściej pełniły sąsiednie place lub rynki. Obserwując współczesne polskie cmentarze w okresie świąt kościelnych, w tym w dniu Wszystkich Świętych, można wymienić różne, podobne do wcześniej opisanych sposoby wykorzystania otoczenia nekropolii. W Polsce w ich pobliżu również znajdują się kramy, stragany z zabawkami i mała gastronomia. Na tym terenie także odbywają się spacery, wieczorne przechadzki i „zabawy z duchami". Cmentarz od czasów średniowiecza - z przerwą w okresie XVI-XVIII w. - do dnia dzisiejszego stanowi nie tylko przestrzeń sacrum, ale również publiczna, profanum, poznawcza, a w konsekwencji - rekreacyjną i turystyczną (Tanaś, 2008).

Wraz z kolonizacją Ameryki Łacińskiej i narzuceniem ludności autochtonicznej kanonu chrześcijańskiego, rdzenni mieszkańcy żyjący w zakładanych przez Europejczyków miastach przejęli z czasem typową dla Starego Kontynentu obrzędowość związaną ze zmarłymi, w tym sposoby organizacji cmentarzy, ale z zachowaniem elementów tradycji indiańskich. Mocno zakorzenione $\mathrm{w}$ autochtonicznym społeczeństwie wierzenia sprawiły, że sfera sacrum (również cmentarze), stała się przestrzenią synkretyzmu kulturowego. Współcześnie w Ameryce Łacińskiej obserwujemy swego rodzaju tygiel kulturowy, będący konglomeratem symboliki indiańskiej i chrześcijańskiej. Ta odmienność, a jednocześnie bliskość kultury europejskiej sprawiła, że latynoamerykańskie cmentarze stały się celem kulturowych podróży turystycznych (Cano, Mysyk, 2004; Miller, Space, 2006).

\section{LISTOPADOWE ŚWIĘTA KU CZCI ZMARŁYCH}

Dzień Wszystkich Świętych jest świętem chrześcijańskim ku czci tych, którzy dostąpili zbawienia i przebywają w niebie. Święto to zostało zapoczątkowane w IV w., kiedy w pierwszą niedzielę po Zesłaniu Ducha Świętego obchodzono uroczystości poświęcone męczennikom (w Kościele prawosławnym zachowany został zwyczaj wspominania w tym dniu wszystkich świętych). W polskiej tradycji ludowej Zesłanie Ducha Świętego, zwane też Zielonymi Świątkami, przypada pięćdziesiąt dni po Niedzieli Zmartwychwstania
Pańskiego, a jego ważnym elementem jest m.in. pamięć zmarłych przodków (szczególnie w Kościele prawosławnym). W 609 r. papież Bonifacy IV urzeczywistnił ideę święta, gdy starożytną świątynię rzymską ku czci wszystkich bóstw (Panteon) poświęcił Matce Boskiej i świętym męczennikom, oraz zdecydował, że główne uroczystości będą przypadały 13 maja. W 835 r. papież Grzegorz IV ustanowił osobne święto ku czci wszystkich świętych, wyznaczając je na 1 listopada. Inicjatorem Dnia Zadusznego, poświęconego pamięci wiernych, zmarłych i cierpiących w czyśćcu, był opat Odilon z Cluny, który w 998 r. polecił, aby we wszystkich klasztorach kluniackich 1 listopada odbywało się oficjum za zmarłych. Z czasem święto przyjęło się w całym Kościele zachodnim i zaczęło być obchodzone 2 listopada. Obecnie dzień Wszystkich Świętych w Kościele katolickim związany jest ściśle z Dniem Zadusznym (Kupisiński, 2007).

W polskiej tradycji dzień Wszystkich Świętych i Zaduszki są czasem zadumy i wspominania zmarłych. Jednak zwyczaj odwiedzania grobów odznacza się również cechami ekumenicznymi i świeckimi (zob. Lewandowski, 2003). Chęć odwiedzenia grobów przodków i członków wspólnot skutkuje wzmożonym ruchem migracyjnym na obszarze całego kraju. W obsługe podróżujących zaangażowane są organy państwa, przedsiębiorstwa transportowe, usługowe i handlowe. Polacy pokonują znaczne odległości, powracając na krótki czas do miejscowości, w których się urodzili lub z których pochodza, lub do miejsc związanych z historią swojego życia, rodziny, bliskich, narodu.

W dniach 1 (wigilia) i 2 listopada w Ameryce Łacińskiej dwudniowe obchody, zwane potocznie Dniem lub Świętem Zmarłych (Día de los Muertos, Día de los Difuntos, Fiesta de las Natitas, Fet Gede, Arawng mga Patay), są synkretycznym połączeniem praktyk z dnia Wszystkich Świętych i Dnia Zadusznego z prekolumbijskimi rytuałami ku czci przodków. W szczególności odznaczają się cechami karnawału w Meksyku, Gwatemali, Peru, Boliwii, Haiti i na Filipinach, gdzie cmentarz jest miejscem spotkań rodzinnych ze zmarłym, upływających raczej $\mathrm{w}$ atmosferze radości i zabawy, ale również tajemniczości życia pozagrobowego (Jaszczak, Dreksler, 2013)

Obchody świąt w Ameryce Łacińskiej różnią się w zależności od kraju i regionu, obejmują jednak kluczowe praktyki, jak: odnawianie, czyszczenie, malowanie rodzinnych grobów, nagrobków i krzyży, ozdabianie i dekorowanie grobów kwiatami i świecami, budowanie symbolicznych ołtarzy w domach lub na grobach, przygotowywanie świątecznych posiłków i napojów, modlitwy za dusze zmarłych oraz udział w mszach świętych. W rdzennych regionach Ameryki Łacińskiej, takich jak: południowy Meksyk, obszary zamieszkałe przez Majów czy region andyjski, rodziny angażują się na cmentarzach w rozwinięte rytuały, na które składają 
się m.in. śpiew, taniec, pikniki, pozostawianie żywności dla zmarłych na grobach lub w grobowcach, nocne oczekiwanie na duchy zmarłych, gry rytualne, a na obszarze Gwatemali puszczanie latawców na powitanie dusz zmarłych. Wielu rdzennych mieszkańców przygotowuje specjalne ołtarze poświęcone zmarłym, dekorowane kwiatami, świecami, kadzidłami, z eksponowanymi pamiątkami i specjalnie przygotowanym jedzeniem. W Meksyku słodycze w kształcie czaszek, wykonane $\mathrm{z}$ formowanego białego cukru oraz ozdabiane kolorowym lukrem, stały się rozpoznawalnym na całym świecie symbolem Dnia Zmarłych.

W światopoglądzie Azteków, Majów, Olmeków i innych rolniczych ludów Ameryki, utrzymywanie harmonii między światami żywych i umarłych było przed przybyciem Europejczyków kluczowym elementem wierzeń. Przez cały rok kalendarzowy odbywały się festiwale ku czci zmarłych, które odgrywały i nadal odgrywają istotną rolę w utrzymywaniu relacji społecznych. W Ameryce Łacińskiej takie rytuały, jak: odnawianie grobów, budowanie ołtarzy czy przygotowywanie specjalnych posiłków na święta, wymagają współpracy członków rodziny i przyjaciół, którzy spotykają się, wspólnie modlą się za dusze zmarłych, odwiedzają przygotowane przez innych ołtarze, dzielą się świątecznymi potrawami w celu oddania szacunku zmarłym. Wymienione czynności stanowią również potwierdzenie zbiorowej tożsamości i solidarności i wskazują na świecki charakter tradycji (Brandes, 1998a, 1998b; Marchi, 2013).

\section{METODOLOGIA I WYNIKI BADAŃ}

W 2004 r. autor artykułu przeprowadził badania na obszarze Łodzi, mające na celu oszacowanie liczby osób, które odwiedziły w dniu 1 listopada wybrane cmentarze. Wielkość ruchu została oszacowana wówczas metodą polegającą na zliczeniu osób wchodzących na cmentarze w dwuminutowych przedziałach czasowych, co pół godziny, pomiędzy 6.00 a 22.00. W grupie badanych cmentarzy znalazły się największe nekropolie łódzkie. W 2019 r. autor postanowił zweryfikować tą samą metodą wyniki badań przeprowadzonych w dniu Wszystkich Świętych 15 lat wcześniej. Badania polegały na zliczeniu odwiedzających wybrane łódzkie cmentarze oraz inwentaryzacji zagospodarowania wokół nich. Ponadto autor wykorzystał w trakcie realizacji zadania badawczego metody obserwacji uczestniczącej i dokumentacji fotograficznej. Pogoda w obu okresach, w których odbywały się badania, była porównywalna, słoneczna z temperaturą sprzyjającą spacerom.

Badaniami porównawczymi objęto dwie grupy cmentarzy na obszarze Łodzi, były to cmentarze na Dołach oraz na Zarzewie (rys. 1).

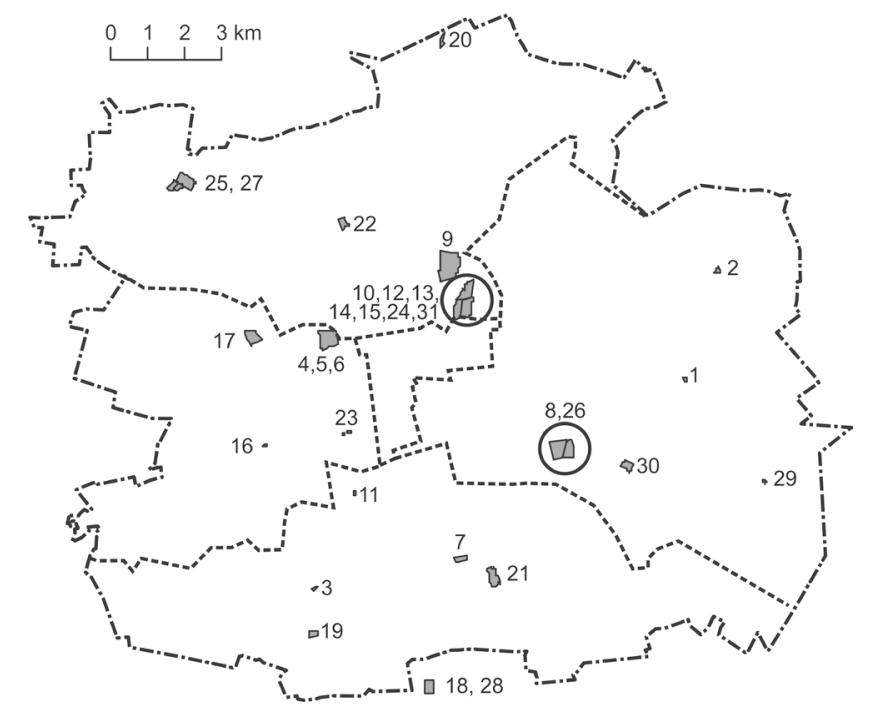

Rysunek 1. Rozmieszczenie cmentarzy w Łodzi w 2005 r.

1 - „Mileszki” (katolicki św. Doroty i św. Jana Chrzciciela) -ul. Frezjowa, 2- „Nowosolna” (katolicki św. A. Boboli)-ul. J. Kasprowicza, 3- „Sopocka” (ewangelicki)-ul. Sopocka, 4, 5, 6- „Stary Cmentarz" (katolicki św. Józefa, ewangelicki, prawosławny) - ul. Ogrodowa, 7 - „Rzgowska” (katolicki św. Franciszka) - ul. Rzgowska, 8, 26 - "Zarzew” (katolicki św. Anny, komunalny) - ul. Lodowa, Przybyszewskiego, 9 - „Bracka” (żydowski) - ul. Bracka, 11 - „Piękna” (ewangelików reformowanych) - ul. Piękna, 10, 12, 13, 14, 15, 24, 31 - „Doły” (katolicki św. Wincentego, wojskowy św. Jerzego, komunalny, prawosławny, mariawitów, baptystów, zielonoświątkowców) - ul. Wojska Polskiego, Smutna, Telefoniczna, 16 - „Retkinia” (katolicki) - ul. Retkińska, 17 - „Mania” (katolicki św. Antoniego) - ul. Solec, 18, 28 - „Starowa Góra" (katolicki św. Maksymiliana Kolbego, wojenny), 19 - "Ruda” (katolicki) - ul. Mierzejowa, 20 - "Łagiewniki” (katolicki), 21 - „Kurczaki” (katolicki św. Wojciecha) - ul. Kurczaki, 22 - „Radogoszcz” (katolicki) - ul. Zgierska, 23 - „Park Poniatowskiego" (wojenny) - ul. S. Żeromskiego, 25, 27 - „Szczecińska" (katolicki MB Nieustającej Pomocy, komunalny) - ul. Szczecińska, 29 - „Andrzejów” (katolicki NP NMP), 30 - „Zakładowa" (katolicki) - ul. Zakładowa

Źródło: opracowanie własne

Historia badanych cmentarzy początkowo związana była z dwoma wsiami - Doły i Zarzew, które zostały przyłączone do Łodzi w latach 1906 i 1915. W 1896 r. na terenie wsi Doły zlokalizowano cmentarz przeznaczony dla protestantów i katolików (współcześnie cmentarz św. Wincentego). Z czasem wyznaczono również cmentarze dla prawosławnych (1905 r.), baptystów (1910 r.), mariawitów (1906 r.), cmentarz wojskowy (1910 r., cmentarz św. Jerzego) oraz miejsce pochówku mahometan i bezwyznaniowców. W ten sposób Doły stały się ważną dla Łodzi nekropolią. W 1947 r. na Dołach (w znacznej części na obszarze zlikwidowanego cmentarza ewangelickiego) zorganizowano miejski cmentarz komunalny. W 2003 r. został założony cmentarz zielonoświątkowców. Na terenie wsi Zarzew, przy dzisiejszej ul. Lodowej, w 1886 r. został założony cmentarz św. Anny, a w 1975 r. oddano do użytku 
cmentarz komunalny. Łączna powierzchnia cmentarzy na Dołach wynosi 37,6 ha, a na Zarzewie - 29,9 ha. $\mathrm{W}$ tabeli 1 przedstawiono zestawienie porównawcze powierzchni łódzkich cmentarzy, z wyróżnionymi cmentarzami Doły i Zarzew.

Badanie ruchu odwiedzających cmentarze zogniskowane zostało na ustaleniu liczby osobowejść na ich teren. Autor zaproponował przyjęcie współczynnika a jako wielokrotności wejść na cmentarz w ciagu dnia. Wynikała ona najczęściej z tranzytowego położenia cmentarza i chęci skrócenia przez odwiedzających drogi na grób znajdujący się na cmentarzu sąsiednim lub była spowodowana kilkukrotnymi odwiedzinami grobów w ciągu dnia (Tanaś, 2008).
Według autora z przeprowadzonych obserwacji ruchu na cmentarzach w Łodzi w latach 2004, 2005 i 2019 wynika, że współczynnik a zawiera się w przedziale od 1,5 do 2. Oznacza to, że odwiedzający wchodzili na teren cmentarza średnio od 1,5 do 2 razy w trakcie całego dnia (osoby przychodziły na cmentarz jeden, dwa i kilka razy w ciągu dnia). W przypadku badanych cmentarzy przyjęto współczynnik a na poziomie 1,5 (tab. 2).

Cmentarze Doły zlokalizowane są w północnej części miasta.Wnajwiększym szczycieodwiedzin (w godz.10.0012.00) na cmentarze w $2004 \mathrm{r}$. w ciagu jednej godziny wchodziło ok. 27 tys. osób, a w 2019 r. ok. 26,5 tys. osób. W 2004 r. w ciągu całego dnia Wszystkich Świętych (w godz. 6.00-22.00) na Dołach odnotowano ok. 270 tys.

Tabela 1. Cmentarze w Łodzi

\begin{tabular}{|c|c|c|}
\hline Cmentarz & Rok założenia & $\begin{array}{l}\text { Powierzchnia } \\
\text { (w ha) }\end{array}$ \\
\hline Św. Doroty i św. Jana Chrzciciela - Mileszki & XIX w. & 1,0 \\
\hline Św. Andrzeja Boboli - Nowosolna & 1846 & 2,0 \\
\hline Ewangelicki - ul. Sopocka & 1850 & 1,1 \\
\hline Św. Józefa - ul. Ogrodowa & 1855 & 10,6 \\
\hline Prawosławny - ul. Srebrzyńska & 1855 & 0,7 \\
\hline Ewangelicki - ul. Ogrodowa & 1855 & 9,5 \\
\hline Św. Franciszka - ul. Rzgowska & 1882 & 4,8 \\
\hline Św. Anny - ul. Lodowa (Zarzew) & 1886 & 18,5 \\
\hline Żydowski - ul. Bracka & 1892 & 42,0 \\
\hline Św. Wincentego - ul. Smutna (Doły) & 1896 & 17,0 \\
\hline Ewangelików Reformowanych - ul. Piękna & 1904 & 0,6 \\
\hline Prawosławny - ul. Telefoniczna (Doły) & 1905 & 1,9 \\
\hline Mariawitów - ul. Wojska Polskiego (Doły) & 1906 & 0,8 \\
\hline Św. Jerzego - ul. Wojska Polskiego (Doły) & 1910 & 2,7 \\
\hline Baptystów - ul. Telefoniczna (Doły) & 1910 & 1,5 \\
\hline Retkinia - parafialny - ul. Retkińska & 1913 & 1,0 \\
\hline Św. Antoniego - ul. Solec (Mania) & 1914 & 11,0 \\
\hline Wojenny z I wojny światowej - Gadka Stara & 1914 & 5,2 \\
\hline Ruda - parafialny - ul. Mierzejowa & 1917 & 3,3 \\
\hline Łagiewniki - parafialny - ul. Okólna & 1918 & 1,1 \\
\hline Św. Wojciecha - ul. Kurczaki & 1924 & 15,0 \\
\hline Św. Rocha - ul. Zgierska (Radogoszcz) & 1925 & 5,5 \\
\hline Wojenny z II wojny światowej - park Józefa Poniatowskiego & 1945 & 0,3 \\
\hline Komunalny - ul. Smutna (Doły) & 1947 & 12,0 \\
\hline Matki Boskiej Nieustającej Pomocy - ul. Szczecińska & 1949 & 22,0 \\
\hline Komunalny - ul. Przybyszewskiego (Zarzew) & 1975 & 11,4 \\
\hline Komunalny - ul. Hodowlana (Szczecińska) & 1988 & 5,6 \\
\hline Św. Maksymiliana Marii Kolbego - Gadka Stara & 1991 & 5,5 \\
\hline Niepokalanego Poczęcia Najświętszej Marii Panny - Andrzejów & 1992 & 2,9 \\
\hline Wszystkich Świętych - ul. Zakładowa & 2000 & 7,0 \\
\hline Zielonoświątkowców - ul. Smutna (Doły) & 2003 & 2,5 \\
\hline
\end{tabular}

Źródło: opracowanie własne na podstawie danych z administracji cmentarzy oraz Wojewódzkiego Konserwatora Zabytków. 
Tabela 2. Liczba osobowejść na badane cmentarze w dniu 1.11.2004 r. i 1.11.2019 r.

\begin{tabular}{|c|c|c|c|c|c|c|c|}
\hline \multirow{3}{*}{ Cmentarz } & \multirow{3}{*}{$\begin{array}{l}\text { Powierzchnia cmentarza } \\
\text { (ha) }\end{array}$} & \multicolumn{6}{|c|}{ Wielokrotność wejść na cmentarz (A) w tys. osób } \\
\hline & & \multicolumn{2}{|c|}{1} & \multicolumn{2}{|c|}{1,5} & \multicolumn{2}{|c|}{2} \\
\hline & & 2004 & 2019 & 2004 & 2019 & 2004 & 2019 \\
\hline Doły & 37,6 & 270,0 & 264,0 & 180,0 & 176,0 & 135,0 & 132,0 \\
\hline Zarzew & 29,9 & 203,0 & 162,0 & 135,3 & 108,0 & 101,5 & 81,0 \\
\hline
\end{tabular}

Źródło: opracowanie własne na podstawie Tanaś (2008).

osobowejść na siedem cmentarzy, natomiast w 2019 r. - 264 tys. Liczba osobowejść w ciągu 15 lat zmniejszyła się jedynie o mniej więcej 3\%. Przy przyjęciu współczynnika a =1,5 cmentarze Doły odwiedziło 1 listopada ok. 180 tys. osób w 2004 r. i 176 tys. w 2019 r. Wyniki są zatem bardzo porównywalne, jeśli założy się pomyłkę statystyczną na poziomie 3-5\%.

Cmentarze Zarzew zlokalizowane są w południowo-wschodniej części miasta, w pobliżu dużego osiedla mieszkaniowego Widzew. W największym szczycie odwiedzin (w godz. 10.00-12.00) na cmentarze w 2004 r. wchodziło w ciągu jednej godziny ok. 22 tys. osób, a w 2019 r. - ok. 18 tys. Jest to spadek o mniej więcej 20\% w ciągu 15 lat. Łącznie w dniu Wszystkich Świętych (w godz.6.00-22.00) w 2004r. odnotowano ok. 203 tys. osobowejść na cmentarze zarzewskie, a w 2019 r. - 162 tys. Spadek liczby osobowejść wyniósł zatem w ciągu 15 lat ok. 20\%. Przy założeniu współczynnika a =1,5, cmentarze Zarzew odwiedziło ok. 135 tys. osób w 2004 r. i 108 tys. w 2019 r.

Łącznie w 2004 roku na badane cmentarze (przy założeniu współczynnika a=1,5) przyszło ok. 315 tys. osób, a w 2019 r. - 284 tys. Jest to spadek łącznej liczby odwiedzających o mniej więcej $10 \%$. Należy zaznaczyć, że Łódź w 2004 r. zamieszkiwało 774 tys. osób, a w 2019 r. niewiele ponad 685 tys., co oznacza, że w tym czasie odnotowano spadek liczby mieszkańców Łodzi o $11,5 \%$.

Przeprowadzone przez autora w 2004 r. badania nad głównymi przyczynami przychodzenia na cmentarze $\mathrm{w}$ dniu 1 listopada ${ }^{2}$ wykazały m.in., że na Dołach $8 \%$ ankietowanych wskazało na spacer (3\%) i motyw poznawczy (5\%), z kolei na Zarzewie deklarację taką złożyło $7 \%$ badanych (5\% zadeklarowało spacer, $2 \%$ motyw poznawczy). Były to osoby niemające na odwiedzanych cmentarzach pochowanych członków rodziny i znajomych. Choć różnice są niewielkie, to jednak motyw poznawczy przeważył na Dołach. Powodem może być fakt zlokalizowania na cmentarzu komunalnym i wojskowym pomników wybitnych łodzian. Dla porównania na zabytkowym Starym Cmentarzu przy ul. Ogrodowej spacer w celach rekreacyjnych i poznawczych zadeklarowało w tym dniu aż $12 \%$ badanych, którzy nie odwiedzali grobów swoich bliskich. Wyniki badań dotyczących motywów, jakimi kierowali się odwiedzający cmentarze 1 listopada, wskazują wyraźnie na tradycję spacerów o charakterze rekreacyjnym, podejmowanych ze względu na wyjątkową atmosferę panującą w tych miejscach.

Poza próbą weryfikacji liczby osób odwiedzających cmentarze w latach 2004 i 2019, w 2019 r. została również przeprowadzona inwentaryzacja punktów handlowych, w tym gastronomicznych, zlokalizowanych wokół badanych cmentarzy. Liczba działających straganów może świadczyć o znaczeniu handlu i gastronomii w dniu Wszystkich Świętych, zarówno dla sprzedawców, jak i dla samych mieszkańców tych terenów. W przeważającej liczbie zinwentaryzowanych punktów handlowych oferowano kwiaty, znicze i artykuły dekoracyjne (w tym dewocjonalia). Uwagę odwiedzających zwracały punkty gastronomiczne (w kilkunastu przypadkach wraz z rozstawionymi dla konsumentów stołami i ławkami), w których serwowano m.in. dania ciepłe (z grilla), oscypki (w tym z grilla), hamburgery i hot dogi, lody, watę cukrowa, słodycze oraz obwarzanki, których sprzedaż w tym dniu jest swoistą łódzką tradycją. Komentarze, ale i zainteresowanie, wywoływały punkty sprzedaży zabawek, w większości zaopatrzone w balony. Obserwacja uczestnicząca - prowadzona w szczególności na ul. Smutnej na Dołach oraz na ul. Przybyszewskiego na Zarzewie - w ramach której autor odnotował m.in. gwar, spacerową i odświętną atmosferę, woń smażonych specjałów, dzieci z balonami, osoby konsumujące watę cukrową i lody, jednoznacznie wskazuje na jarmarczny charakter święta, zbliżony atmosferą do uroczystości odpustu parafialnego czy festynu.

Choć atmosfera jarmarku i odpustu, dająca się odczuć w otoczeniu objętych badaniem cmentarzy, niekiedy była przyczyną zachowań i komentarzy wskazujących na brak aprobaty punktów gastronomicznych i straganów z zabawkami, to w opinii autora w zdecydowanej większości było to akceptowane. Należy zaznaczyć, że na terenie cmentarzy nie zaobserwowano konsumpcji sprzedawanych na straganach produktów spożywczych. W obrębie cmentarzy zauważono natomiast osoby palące papierosy. W godzinach największego ruchu odwiedzających na terenie cmentarza przy ul. Lodowej stał muzyk grający na skrzypcach i wykorzystujący przenośne nagłośnienie. Zaobserwowano łącznie pięć osób żebrzących w obrębie cmentarzy (przy ul. Lodowej, Przybyszewskiego oraz Smutnej). 
Wokół cmentarzy na Dołach było zlokalizowanych 230 punktów handlowych z kwiatami, zniczami, asortymentem dekoracyjnym, w tym 8 punktów z zabawkami, balonami i dewocjonaliami oraz 30 punktów gastronomicznych, w których oferowano ciepłe dania, pieczywo, hot dogi, oscypki na ciepło, popcorn, watę cukrowa, lody oraz obwarzanki (7 punktów) (rys. 2).

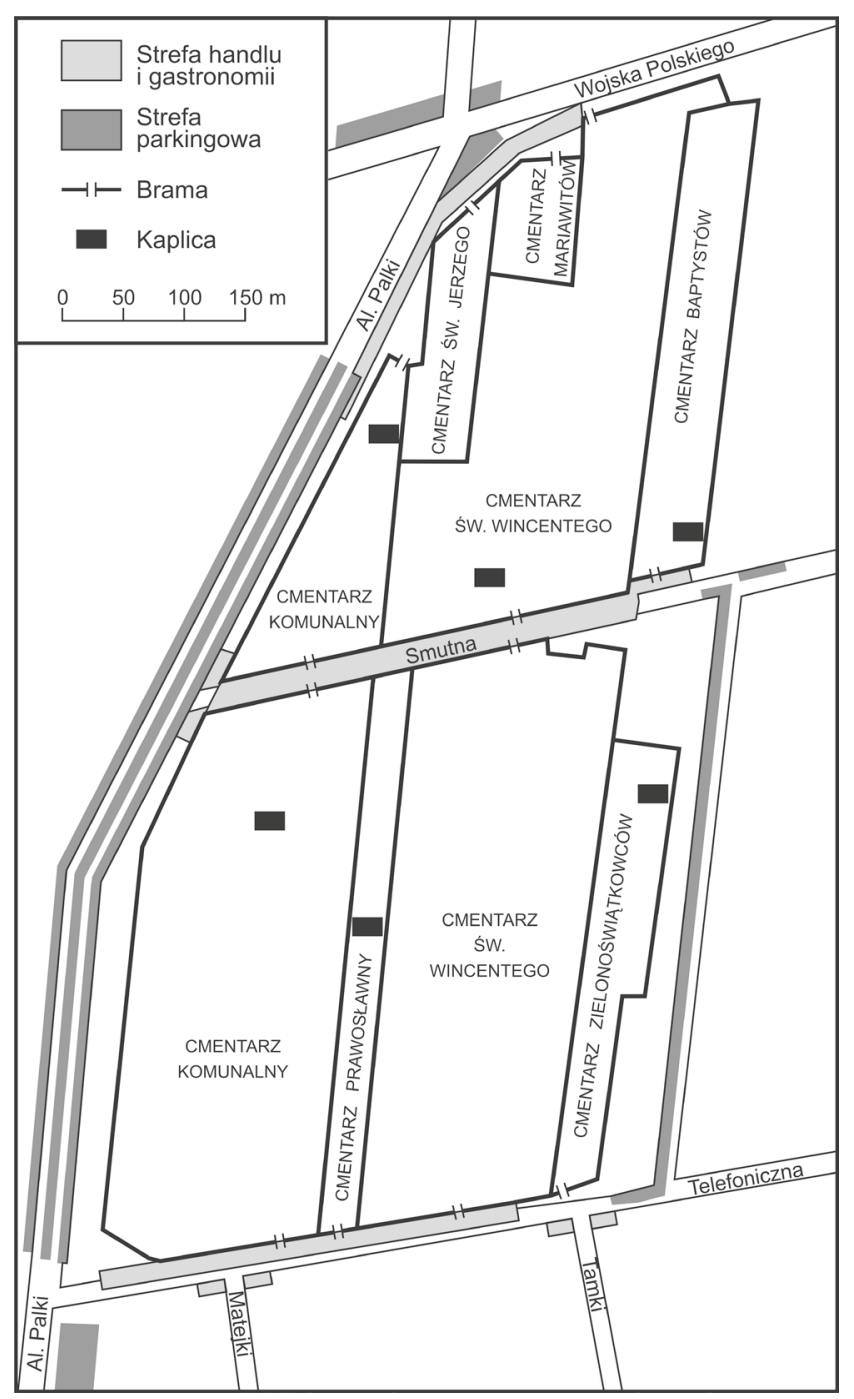

Rysunek 2. Zagospodarowanie otoczenia cmentarzy Doły Źródło: opracowanie własne

Dla porównania przez trzy niedziele maja $2020 \mathrm{r}$. w okolicach tych cmentarzy odnotowano średnio 22 punkty handlowe, w tym 10 punktów stałej dystrybucji oraz 12 rozkładanych straganów, dysponujących w sprzedaży kwiatami, zniczami i asortymentem dekoracyjnym. Nie było natomiast punktów gastronomicznych.

Wokół cmentarzy na Zarzewie było zlokalizowanych 229 punktów handlowych, z kwiatami, zniczami, asortymentem dekoracyjnym, w tym 6 punktów z zabawkami, balonami i dewocjonaliami oraz 18 punktów gastronomicznych, w których oferowano ciepłe dania, pieczywo, hot dogi, oscypki, popcorn, watę cukrowa, lody oraz obwarzanki (7 punktów) (rys. 3). Dla porównania liczba punktów handlowych odnotowanych w trzy niedziele maja $2020 \mathrm{r}$. wyniosła po uśrednieniu 12 punktów stałej dystrybucji oraz 8 rozkładanych straganów, na których sprzedawano jedynie kwiaty, znicze i asortyment dekoracyjny. Łącznie było to 20 punktów handlowych. Również w okolicach tego cmentarza nie zauważono punktów gastronomicznych. Porównując zagospodarowanie handlowe 1 listopada i w majową niedzielę wokół obu badanych grup cmentarzy, odnotowano ponaddziesięciokrotny wzrost liczby punktów handlowych w dniu Wszystkich Świętych.

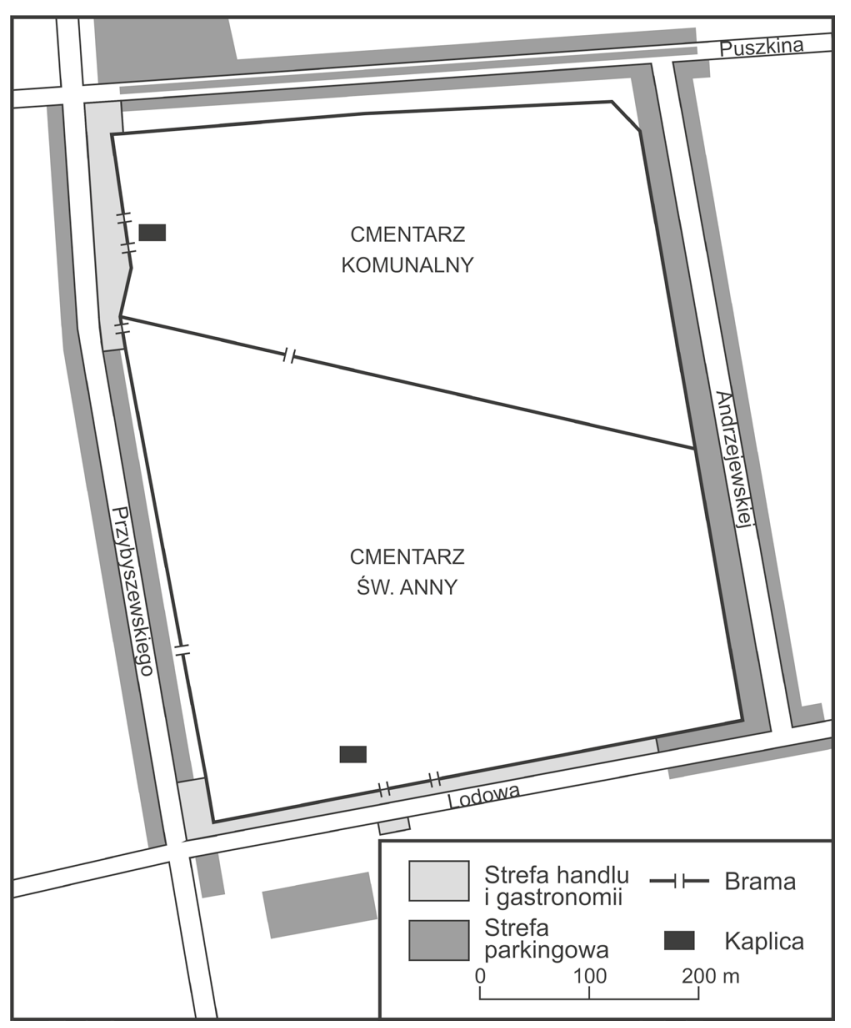

Rysunek 3. Zagospodarowanie otoczenia cmentarzy Zarzew Źródło: opracowanie własne

Na parkingach, zorganizowanych na przylegających bezpośrednio do zarzewskich cmentarzy ulicach Lodowej, Przybyszewskiego, Puszkina i Andrzejewskiej, w godzinach 10.00-12.00 jednorazowo zliczono ok. 3 tys. zaparkowanych pojazdów samochodowych.

Z przeprowadzonych w $2005 \mathrm{r}$. przez autora badań wynika, że ok. $85 \%$ ankietowanych dorosłych osób odwiedziło cmentarz co najmniej raz $\mathrm{w}$ roku - w dniu Wszystkich Świętych. W Polsce coraz częściej 1 i 2 listopada cmentarze i groby są nie tylko odwiedzane ze względu na obowiązek religijny, obywatelski czy rodzinny, ale również stanowią cel spacerów wolnoczasowych o charakterze poznawczym i rekreacyjnym, 
na co wskazują prowadzone przez autora badania nad powodami odwiedzin cmentarzy (Tanaś, 2008; zob. też: Kulczyńska, Marciniak, 2018).

\section{PODSUMOWANIE}

Współczesny charakter listopadowych świąt ku czci zmarłych można uznać za skutek dystrybucji elementów kultury w drodze zapożyczeń - dyfuzji kulturowej, czego konsekwencją jest ich synkretyzm. Sposób obchodzenia dnia Wszystkich Świętych w Polsce oraz Święta Zmarłych w Ameryce Łacińskiej jest odmienny, ale można wskazać wspólne cechy tych uroczystości, co autor starał się wykazać w niniejszym artykule.

Globalizacja, powszechność dystrybucji informacji i wiedzy, rozwój kultury masowej oraz wpływ innych kultur na polskie obyczaje wywołuje niewątpliwie postępującą laicyzację dnia Wszystkich Świętych oraz jego pogłębiającą się komercjalizację.

Dzień Wszystkich Świętych jest świętem Kościoła chrześcijańskiego, obchodzonym we wszystkich jego odłamach, choć nie zawsze wiąże się z tradycją nawiedzenia grobu. Atmosfera tego dnia oraz siła tradycji udziela się większości społeczeństwa polskiego, niezależnie od tego, czy mowa o osobach wierzących czy nie. W dobie postępującej globalnej komunikacji oraz komercjalizacji życia charakter świąt ku czci zmarłych ulega ciągłym przemianom.

Należy pamiętać, że dzień Wszystkich Świętych ma najistotniejsze znaczenie $\mathrm{w}$ procesie edukacyjnej promocji cmentarzy, poszerzania świadomości krajoznawczej i budowania wspólnot lokalnych oraz poczucia więzi obywatelskich na gruncie szacunku wobec przodków i historii. Nekropolie są w tym czasie przedmiotem przekazu medialnego, miejscem spacerów, edukacji rodzinnej i patriotycznej, celem wycieczek krajoznawczych. Ważną rolę w procesie edukacji w zakresie zachowania dziedzictwa artystycznego i historycznego polskich cmentarzy odgrywają kwesty, podczas których zbierane są środki przeznaczane później na ratowanie zabytkowych pomników. Zbiórki pieniężne zapoczątkował J. Waldorf, który w 1974 r. założył Społeczny Komitet Opieki na rzecz Ochrony Starych Powązek i tym samym rozpoczął nową tradycję pierwszolistopadowych kwest.

„Popkulturyzacja” dnia Wszystkich Świętych jest faktem, a ewolucja motywów odwiedzania cmentarzy na początku listopada jest ściśle powiązana ze zmianami społeczno-gospodarczymi i cywilizacyjnymi, w tym z postępującą laicyzacją społeczeństwa. Świecki charakter wizyt na cmentarzach wykazuje cechy jarmarczności, kulturowej globalizacji i komercjalizacji, wręcz festynu, co potwierdza tezę, że podobnie jak meksykański Dzień
Zmarłych, polski dzień Wszystkich Świętych może być uznany za kulturowy produkt turystyczny.

Autor starał się wykazać w niniejszym artykule społeczne znaczenie cmentarzy, koncentrujące się nie tylko wokół wartości religijnych, ale również świeckich, w tym prawdopodobnie niedocenianej funkcji terapeutycznej i regeneracyjnej nekropolii, ich wpływu na kształtowanie pożądanych postaw wspólnotowych, takich jak patriotyzm i obywatelskość. Społeczna rola, jaką odgrywają cmentarze, jest szczególnie widoczna na początku listopada zarówno w Polsce, jak i w Ameryce Łacińskiej. Choć zmieniająca się ideologia kultu zmarłych, zarówno w sferze sacrum, jak i w dyskutowanym wymiarze profanum, podatna jest na cykliczność zmian kulturowych, to masowość odwiedzin cmentarzy w dniu Wszystkich Świętych w Polsce i w święta ku czci zmarłych w Ameryce Łacińskiej świadczy o wadze i potrzebie utrwalania lokalnych więzi społecznych, w tym wzmacniania wspólnot religijnych, rodzinnych i obywatelskich na gruncie pamięci o zmarłych. W tym kontekście walory cmentarzy i kultu zmarłych moga stanowić istotny element składowy kulturowego produktu turystycznego.

\section{PRZYPISY}

\begin{abstract}
${ }^{1}$ Jedną z pierwszych prac poświęconych planowaniu cmentarzy, cytowaną przez wielu późniejszych autorów, jest publikacja Loudona (1843), szkockiego botanika, nestora brytyjskiej szkoły projektowania krajobrazu. Książka ta została szeroko opisana przez Curla (1980) w A celebration of death. W pracy tej autor analizuje koncepcję cmentarza ogrodu. Studia nad ewolucją projektów i założeń architektonicznych cmentarzy prowadzili również m.in. Etlin (1984) i Ragon (1983).

${ }^{2}$ Wyniki badań dotychczas niepublikowane. Dane zostały pozyskane w toku badań ankietowych przeprowadzonych przez studentów Wyższego Seminarium Duchownego w Łodzi podczas kwesty zorganizowanej na terenie badanych cmentarzy w dniach 31.10-1.11.2004 r.
\end{abstract}

\section{BIBLIOGRAFIA}

Ariés, Ph. (1989). Człowiek i śmierć. Warszawa: Państwowy Instytut Wydawniczy.

Brandes, S. (1998a). The Day of the Dead, Halloween, and the quest for Mexican national identity. The Journal of American Folklore, 111 (442), 359-380.

Brandes, S. (1998b). Iconography in Mexico's Day of the Dead: Origins and meaning. Ethnohistory, 45 (2), 181-218.

Cano, L.M., Mysyk, A. (2004). Cultural tourism. The state and Day of the Dead. Annals for Tourism Research, 31 (4), 879-898. Curl, J.S. (1980). A celebration of death. London: Constable.

Długozima, A. (2011). Cmentarze jako ogrody żywych $i$ umartych. Warszawa: Wydawnictwo Sztuka ogrodu, Sztuka krajobrazu Beata Gawryszewska. 
Eliade, M. (1996). Sacrum i profanum. O istocie religijności. Warszawa: Wydawnictwo KR.

Etlin, R.E. (1984). The architecture of death the transformation of the cemetery in eighteenth-century Paris. London: MIT Press, Cambridge, Massachusetts.

Jackowski, A. (2003). Święta przestrzeń świata. Podstawy geografii religii. Kraków: Wydawnictwo UJ.

Jaszczak, A., Dreksler, B. (2013). Cmentarze - miejsca pamięci, tradycji i religii. Cmentarze i ogrody w krajobrazie. O sacrum, symbolice, kompozycji i przemijaniu. Prace Komisji Krajobrazu Kulturowego, 22, 31-39.

Kolbuszewski, J. (1985). Wiersze z cmentarza. O wspótczesnej epigrafice wierszowanej. Warszawa: Polskie Towarzystwo Ludoznawcze.

Kolbuszewski, J. (1996). Cmentarze. Wrocław: Wydawnictwo Dolnośląskie.

Kulczyńska, K., Marciniak, N. (2018). Odwiedzenia nekropolii na Miłostowie w Poznaniu i ich motywy. Rozwój Regionalny i Polityka Regionalna, 44, 205-219.

Kupisiński, Z. (2007). Śmierć jako wydarzenie eschatyczne. Lublin: Wydawnictwo KUL.

Lewandowski, R. (2003). Idea śmierci w kontekście Święta Zmarlych. Anthropos? 1, 54-85
Loudon, C.J. (1843). On the laying out, planting and managing of cemeteries and on the improvement of churchyards. Londyn: [b.w.].

Marchi, R. (2013). Hybridity and authenticity in US Day of the Dead celebrations. Journal of American Folklore, 126 (501), 272-301.

Miller, M.S., Space, J.D. (2006). Hallowed ground, place, and culture: The cemetery and the creation of place. Space and Culture, 9 (4), 334-350.

Ragon, M. (1983). The space of death. A study of funerary architecture, decoration, and urbanism. Charlottesville: University Press of Virginia.

Stasiak, A., Tanaś, S. (2005). Przestrzeń sepulkralna w turystyce. Turystyka i Hotelarstwo, 8, 9-42.

Tanaś, S. (2008). Przestrzeń turystyczna cmentarzy. Wstęp do tanatoturystyki. Łódź: Wydawnictwo Uniwersytetu Łódzkiego.

Artykuł wpłyną:

24 czerwca $2020 \mathrm{r}$.

Zaakceptowano do druku:

23 października $2020 \mathrm{r}$. 